\title{
Parliamentary Experience of the Turkish Labor Party: 1965-1969
}

\section{Erkan Doğan}

To cite this article: Erkan Doğan (2010) Parliamentary Experience of the Turkish Labor Party: 1965-1969, Turkish Studies, 11:3, 313-328, DOI: 10.1080/14683849.2010.506722

To link to this article: http://dx.doi.org/10.1080/14683849.2010.506722

$$
\text { 册 Published online: } 21 \text { Sep } 2010 .
$$

Submit your article to this journal $[\pi$

Џlll Article views: 188

Q View related articles $\sqsubset$ 
Vol. 11, No. 3, 313-328, September 2010

\title{
Parliamentary Experience of the Turkish Labor Party: 1965-1969
}

\author{
ERKAN DOĞAN* \\ Department of Political Science, Bilkent University
}

\begin{abstract}
This study is a political historical account of the significance of the Turkish Labor Party (TLP) (Türkiye İşçi Partisi) in Turkish politics and among the Turkish left in light of the party's parliamentary experience between 1965 and 1969. The TLP's entrance into the National Assembly was an important milestone and a unique phenomenon in modern Turkish politics. The TLP's insistence on the use of parliamentary and constitutional means to come to power was its distinctive feature; and it was this characteristic that distinguished the party from other main organizations and movements of the Turkish left in the 1960s.
\end{abstract}

The Turkish Labor Party (TLP) (Türkiye Isşci Partisi) was founded just after the military intervention in 1960. Although various socialist movements and parties had been formed in the past, none of them has had as serious an impact on Turkish politics as the TLP went on to have. The TLP's entry into the National Assembly in 1965 considerably increased its significance both within the Turkish leftist movement and Turkish politics. For the first time in Turkish history, socialist deputies as members of a socialist party entered the National Assembly and, for the first time, socialist ideas found formal representation in the parliament. In spite of its limited weight in the National Assembly, the party played an important role as part of the parliamentary opposition and left its mark on the Turkish political history of the 1960s.

The TLP, from its very foundation, was always a firm supporter of attaining power through parliamentary means. The party's parliamentary experience was a unique phenomenon in the modern Turkish political history. However, this experience was not strong enough to initiate a new political tradition in the Turkish political system and thus could not be transmitted to the following decades. The movement lost its momentum and failed towards the end of the 1960s and never emerged as an influential political factor afterwards. Although the TLP and the Turkish left, in general, had responsibilities for the failure of this experience, the main institutions and agents of the Turkish political system, having seen the party as

*Correspondence Address: Erkan Doğan, Bilkent University, Department of Political Science, 06800 Bilkent, Ankara, Turkey. Email: erkando@bilkent.edu.tr 


\section{E. Doğan}

a real threat to the existing order, did not allow the TLP to function within the constitutional framework and to construct its historical institutional tradition within the same political system.

This article, based on primary documents, first, outlines some of the general characteristics of the Turkish left during the 1960s, and then, concentrates on the different methods of attaining political power proposed by the main Turkish leftist factions of the period. After entering the parliament, the political and ideological authority of the TLP over other sections of the Turkish left increased considerably. However, this never meant that the parliamentarist strategy of the TLP was not challenged by the other segments of the movement. By comparing the major leftist groups of the 1960s, I will try to present briefly the main distinguishing feature of the TLP, its insistence on parliamentary and constitutional means to come to power. The last section traces the experiences of the TLP in the National Assembly after 1965. ${ }^{1}$ In this section, first, the part played by the TLP in the 1965 general elections, which was the first major political test of the party, is examined; and then, the parliamentary performance of the TLP is analyzed.

\section{Turkish Socialism in the 1960s}

The decade following the military coup of May 27, 1960, which marked a turning point in Turkish political history, was a period of rapid transformation in many aspects. Although the foundations of the regime remained the same, the way politics was carried out had been changed. In this period, the universities were guaranteed greater autonomy; students were given freedom to organize their own associations; and trade unions were given the right to strike and engage in collective bargaining. The politicization of the intelligentsia, students, and workers accelerated in the same period as well. Notwithstanding the socio-economic changes in the international and domestic contexts in the Cold War era, which paved the way to the emergence of class politics in Turkey, the involvement of radical leftist political groups in domestic politics increased considerably once they were legally allowed to propagate their ideas and distribute their publications freely within the more liberal context of post1960 Turkey. $^{2}$

The leftist intellectuals of the period genuinely welcomed the military intervention. They considered the coup as a significant moment of Turkish political history since it gave Turkish people a comprehensive constitution. Also, the coup was thought to provide the Turkish socialist movement an important opportunity to organize itself and disseminate its ideas freely within a constitutional framework. ${ }^{3}$ Mehmet Ali Aybar, who later became the chairman of the TLP, was also of the same opinion. In an open letter to President Cemal Gürsel on November 19, 1960, he described the intervention of May 27 as a progressive movement, which, he also believed, would allow establishing prominent socialist parties in Turkey. ${ }^{4}$

Socialism in the 1960s was understood and introduced as an ideology to achieve rapid national modernization and social justice. ${ }^{5}$ The successors of the elite-bureaucratic 
tradition, the socialists of the 1960 s believed in revolution from above. ${ }^{6}$ Most of the Turkish socialist groups were "theoretically and politically shackled to an obsolete and romanticized vision of an alliance between the working masses and a "progressive' state bureaucracy."7 This strategy was best represented by a political group that emerged around a weekly review, Yön (Direction), founded by writer-journalist Doğan Avcioğlu after the military intervention. The programmatic approaches and analyses that determined the political perceptions and perspectives of the Turkish left during the decade were first seen in the pages of this journal. ${ }^{8}$ The "statement" on economic and social development in Turkey that was published in the first issue of Yön gives a general idea about the development strategy, the "philosophy of development", advocated by the group. ${ }^{9}$ It stated that

the attainment of the level of modern civilization, the final solution of the problem of education, the enlivening of Turkish democracy, the realization of social justice and the establishment of democratic regime can only be achieved by rapid economic development led and planned by the state. ${ }^{10}$

Imperialism, feudalism, and the big comprador bourgeoisie were identified as the main obstacles to initiating a rapid economic development and to establishing "national democracy." So, for the Yön movement, the main political task was to construct a national democratic front in which all anti-feudal, anti-imperialist forces would unite in order to carry out a national democratic revolution.

In the second half of the $1960 \mathrm{~s}$, this national democratic revolution strategy also became a dominant characteristic of the National Democratic Revolution (NDR) movement which formed itself first around a journal called Türk Solu (The Turkish Left) published by Mihri Belli and his followers. ${ }^{11}$ Under the leadership of Belli, the NDR movement gained ground among the university students and became one of the significant socialist factions in Turkey in the second half of the decade. In many respects, the political and ideological approaches of this newly shaped movement overlapped with those of the Yön group. The NDR also believed that, in an underdeveloped country like Turkey, the main struggle would be against imperialism and feudalism. Since the proletariat was too weak as a class, revolutionary change could only be carried out by a broad national front of all the exploited social classes and groups, including intellectuals, officers and the national bourgeoisie. This revolution directed against landowners and compradors would have a national and democratic character, not a socialist one.

When compared with the other leftist groups, the impact of the TLP on Turkish politics and the socialist movement was more significant due to several reasons. Above all, the TLP was the main legal party of the left and it served as a "laboratory" for the Turkish socialists. ${ }^{12}$ For the party, the main task of the Turkish socialists was not a national democratic revolution but a socialist transformation which, of course, would be carried out by democratic and constitutional means. Its ideology was an amalgamation of Kemalism, Western social democracy and Marxian socialism. The TLP was established on February 13, 1961 by a group of trade 
union leaders who believed that a political party represented in the parliament could promote and safeguard the interests of the workers. ${ }^{13}$ On February 1, 1962, Mehmet Ali Aybar was offered the leadership of the TLP. After this date, the party entered into a new phase during which it matured into a socialist party and became an active political force in the rest of the 1960s.

From TLP's first national congress in Izmir in 1964, to its fourth congress in Ankara in 1970, the party's strategy and political orientation was persistently an issue of controversy among its ranks. The first serious dispute within TLP members was between the party leadership and the proponents of the NDR strategy. In spite of the enduring opposition of the supporters of the NDR line, the party adopted a strategy advocating the indivisibility of the national-democratic and socialist tasks and adopted it as its official policy in the second half of the 1960s. ${ }^{14}$ This dispute was followed by other factional controversies in the party. ${ }^{15}$ The Soviet invasion of Czechoslovakia in August 1968 deepened and accelerated the political and ideological rifts within the party's leadership. Aybar spoke out against the intervention of the Soviet armed forces. His protest against the invasion also gave him the chance to express his understanding of socialism. He clearly advocated a non-authoritarian, democratic version of socialism. Aybar was accused by other party leaders, such as Behice Boran and Sadun Aren, for adopting new non-scientific theories on socialism. The crisis beginning with the invasion of Czechoslovakia by the Soviet troops was intensified by the failure of the TLP in the 1969 elections. The struggle between the two factions of the party resulted in Aybar's resignation from chairman and his replacement by Boran in 1970.

By early 1971, Turkey was in a state of social unrest. The growing activities of the radical leftist groups and rightist circles, and the increasing militancy of workers' demonstrations weakened the Demirel government to the point of paralysis. Under these circumstances, the chief of the general staff issued a memorandum on March 12, 1971 and interrupted the normal functioning of the parliamentary regime by suspending democratic freedoms. Amidst this political atmosphere, earlier in 1971, the TLP had been accused of supporting the separatist tendencies of the Kurdish people and taken to court by the state authorities. A resolution adopted in the fourth congress of the party in October of 1970 had paved the way for this charge. The resolution had declared that,

It is the natural and requisite revolutionary duty of our Party... to support the struggle of the Kurdish people, to make use of its constitutional citizenship rights and to realize all of its other democratic desires and hopes. ${ }^{16}$

After the March 12 memorandum, on July 20, 1971, the TLP was closed down and most of the party leaders were arrested. After the normalization of the political life following the general elections of 1973, the socialist movement gained momentum again. In this new political atmosphere, the party reorganized under the leadership of Behice Boran and was officially reestablished on May 1, 1975. However, the new 
TLP, having lost its ideological and political hegemony and authority over the entire Turkish left, became a relatively marginal party.

\section{Methods of Attaining Political Power}

There were serious political differences between the main socialist groups of the 1960s regarding the methods of attaining political power. The leaders of the TLP clearly stated, from the very beginning, their intention to follow the constitution and democratic ways and to act within a legal framework to reach their political aims. This intention was clearly expressed in the official party literature. In the party program, it was asserted that

[The TLP] comes to power by democratic electoral methods. By rejecting the exploitation of man by man, remaining loyal to basic human rights and freedoms, it remains in and is removed from the power by elections. ${ }^{17}$

The party program meticulously emphasized the importance of operating within the constitutionalist framework.

The other major left-wing movements of the 1960s, the Yön circle and the NDR movement, on the other hand, paid scant attention to the constitutional and parliamentary struggle for power. The Yön movement proposed a military coup for a regime change led by progressive civil and military bureaucrats and intellectuals. The proponents of the Yön group had serious doubts about the prospects of a regime change in a multi-party system. ${ }^{18}$ For the $Y \ddot{o n}$ circle, the backward social and economic structures and conditions of the country would not allow the progressive forces to come to power by election. Their claim was that in a country with a high illiteracy rate, the voters were under the ideological and political hegemony of the ruling elite (landlords, the comprador bourgeoisie) and as such could not act independently and could easily be manipulated by the reactionary political forces.

Since the parliament was under the influence of the reactionaries and the progressive forces were unable to seize power by electoral methods, from the perspectives of the $Y \ddot{o n}$ circle, a radical transition in Turkey could only be brought about by non-parliamentary means. The vanguard of this transition would be the dynamic forces of the Turkish society under the leadership of the leftist officers within the army, civilian intelligentsia, trade unions, and youth organizations. ${ }^{19}$ Avcioğlu and other leading figures of the Yön circle found that a regime change within the framework of the 1961 constitution could not be realized. Their faith in the constitution was neither blind nor dogmatic. ${ }^{20}$ To elaborate his view, Avcioğlu asked which was more democratic, Atatürk's authoritarian one-party regime aiming at revolutions and land reform, or Demirel's liberal regime which refused to carry out the land reform. He answered by stating "the Atatürk regime was authoritarian but more democratic. The Demirel regime is liberal but less democratic."21 
The NDR strategy, like the Yön group, was in opposition to the TLP's interpretation of the country's social and economic conditions, its political strategy and its parliamentary approach. Mihri Belli, the founding father of the NDR strategy, asserted that in the reactionary parliamentary system of Turkey, believing that a party could carry out change by electoral methods was an illusion and suited only the interests of the conservative elements. ${ }^{22}$ The NDR movement from the end of 1969 onwards experienced inevitable rifts and fragmentations. The organizations established thereafter mainly rested on university students, the most active and militant part of the socialist movement in the late 1960s and early $1970 \mathrm{~s}^{23}$ In the deepening political crisis and the growing social conflicts of the late 1960s, they decided that political agitation was not enough by itself and came to the conclusion that an armed guerilla struggle was necessary to carry out the desired national democratic revolution. The state repressed these guerilla groups and persecuted thousands of revolutionary students and workers after the March 12, 1971 military intervention. ${ }^{24}$ The embryonic guerilla groups were crushed by the intervention, putting a bloody end to the romantic attempts of a generation.

The TLP leadership described these non-parliamentary strategies as petty bourgeoisie claims, since socialism could be built neither by military coups nor by guerilla strategies. For the other leftist groups (the NDR movement and the Yön circle), the preparation of the working class and its allies for power, the increase of their hegemony in domestic politics and the gradual attainment of power by these classes (through getting organized, learning through struggle, raising consciousness in a political organization) was a long, slow, useless way. According to the TLP, supporters of the non-parliamentary strategies wrongly believed that revolutionary intellectuals of petty-bourgeois origin, students and the cadres of revolutionary officers had the force to carry out a revolution and to build socialism. By resting upon these forces, the proponents of non-parliamentary strategies desired to find a shortcut and a rapid way to obtain political power. ${ }^{25}$

According to the members of the party, the 1961 constitution had a social character: it was progressive, in favor of the people and did not present an obstacle to the social development in Turkey. The new constitution, they argued, charged the state to remove all political, economic, and social obstacles which restricted the fundamental rights and freedoms of the individual in such a way as to be incompatible with the principles of individual well-being, social justice and the rule of law; and to bring about the conditions required for the material and spiritual development of the individual. The logical conclusion of this argument was that the complete implementation of the constitution could only be realized by a socialist government. ${ }^{26}$ The TLP leadership chose to struggle within the framework of the constitution, and believed that, within this framework, the transition from capitalism to socialism could be realized in a peaceful and democratic way. ${ }^{27}$ Mehmet Ali Aybar, the chairman of the party, repeatedly asserted that,

Our constitution is, with no doubt, open to socialism... Our constitution with its understanding of state, social order, with its revolutionary character and 
with its principle based on Kuvay-ı Milliyecilik is in favor of the people and labor. For all of these reasons, it is open to socialism and closed to grasping (kaptıkaçtl) capitalism. $^{28}$

But, would the ruling classes and their supporters, America, give permission to the socialist party to attain power by elections? The party's answer was that if the ruling classes and their governments did not give permission to the TLP to win a majority in the parliament and to take power, then they would lose their legitimacy and find themselves behaving out of a constitutional and legal framework. In this situation the party would exercise its right to resist against these unconstitutional and unlawful attempts. Either the ruling classes would eliminate the constitution and establish a fascist order based on terror or the working classes and laborers would defend their rights and overthrow the unlawful government. ${ }^{29}$

\section{The TLP in the National Assembly}

The TLP was established in February 1961, but its significance as a political factor on the Turkish political scene did not become apparent until its entrance into the parliament four years later in October 1965, when it became the first socialist organization to be officially represented in the National Assembly. Although the TLP had limited representation in the parliament, its deputies brought a new political attitude and understanding to parliamentary politics. The party introduced new concepts, such as class politics, class interests, and social justice, into Turkish political life. Their opposition changed the very character of the political debates in the parliament, giving them an ideological essence.

The 1965 general elections were the first major test for the TLP's political performance. Free electoral propaganda and the possibility of getting a small number of spokesmen into the parliament made these elections critical for the party. The TLP also saw the electoral platform as means to spread its political views among a larger part of the population and widen its organization throughout the country. The party had unofficially started its election campaign in January 1965, with a speech by party chairman Mehmet Ali Aybar, who declared that "the coming general elections mark a turning point in Turkish history... In these elections we must get a number of deputies into the parliament." The people's problems would be expressed every day in the parliament by the representatives of the laborers, and in this way, the awakening of the people would be accelerated and the level of the people's organization would be raised significantly. "So that... our laboring people, that is to say, the Turkish Labor Party, in the 1969 general elections, would run for first place."30

The 1965 general elections had essential political differences when compared to the earlier elections. For the first time topics such as socialism, capitalism, land reform, foreign policy and economic development became issues of election campaigns and were debated by a variety of parties with different ideological perspectives. ${ }^{31}$ In the election campaign of 1965 , the TLP differed from the other parties with its insistence on social issues and reforms. The party also used a 
considerably different discourse in its election propaganda. Its manifesto for the 1965 elections started with an address to workers, day laborers, peasants, artisans, clerks, pensioners, Kemalist and social-minded intellectuals. ${ }^{32}$ In the manifesto, it was stated that "we are against all of the other five parties. We are radically different from them: We are the party of the laboring people." So, in the elections, "there are actually two parties contesting: One of them defends the interests of the landlords and snatchers (kapkaççılar); the other party is yours. It is the party of labor, the Turkish Labor Party." 33

The TLP's election campaign mainly emphasized a non-capitalist path of development in its economic orientation. This basically meant that a rapid national economic and social development through capitalism was simply impossible. The TLP advocated a national development strategy, which could be realized only by implementing a planned statism, a policy of nationalization of all heavy industry, foreign trade and banking, and state ownership of all minerals and an extensive land reform. Foreign policy was another major topic discussed by the party during the campaign period. The TLP continuously declared that Turkey was no country's satellite and that it needed to regain its complete independence from the US domination. All treaties tying Turkey with the US and NATO should be abrogated. ${ }^{34}$

During the election campaign, the TLP was not only confronted with financial problems ${ }^{35}$ but also faced with the physical and verbal attacks of other parties. The last situation polarized the political atmosphere, intensified the growing ideological tension during the election campaign. The people who played prominent roles in these attacks for the most part were supporters of the Association for Fighting Communism in Turkey (AFCT) (Türkiye Komünizmle Mücadele Derne ği $)^{36}$ and members of the Justice Party (JP) (Adalet Partisi). The TLP's electoral promises were equated with communism and the party members were accused of being communists, atheists, and enemies of family life. ${ }^{37}$ The attacks were not limited to these facile charges; on several occasions, meetings held by the TLP were sabotaged or assaulted. ${ }^{38}$ The TLP completely rejected the charges of communism. ${ }^{39}$ The party claimed that those who accused the TLP of communism were trying to alienate the masses from the TLP.

In spite of all the problems confronting the TLP during its election campaign, it won 15 seats in the parliament, which allowed the party to form a parliamentary group in the National Assembly. The party had entered the general elections with 382 candidates $^{40}$ and received 276,101 votes (2.82 percent of the total vote). Thirteen of the 15 deputies of the TLP entered the parliament as a result of the national remainder system, which served to strengthen the representation of smaller parties in the parliament. ${ }^{41}$ One of the TLP's most notable promises during the election campaign had been the representation of workers and peasants in the parliament by workers and peasants. However, the favored places had been given to intellectuals and leading members of the party in order to assure their election to the parliament. Only two out of the 15 elected candidates were trade unionists; the others were known leftist intellectuals. ${ }^{42}$ The party did not actually make much of an impact on the working class and peasants in the elections, and received its votes mainly from 
the middle and upper strata of Turkish society. In Zonguldak, for example, an industrial district and one of the most important mining areas of the country with 40,000 miners, the TLP received only 4,856 votes. ${ }^{43}$ The TLP's electoral performance was successful essentially in large cities like Istanbul, Ankara, and Izmir. The total votes coming from these three centers constituted nearly a third of the TLP's total valid votes. $^{44}$

In the elections, the JP received 53 percent of the total votes and won 240 seats in the parliament, giving it an absolute majority in the assembly. The JP was followed by the Republican People's Party (RPP) (Cumhuriyet Halk Partisi), with 29 percent of the votes and 134 seats. The size of the JP's electoral victory and that of the RPP's defeat were greater than expected. ${ }^{45}$ The other impressive result of the elections was the TLP's entrance into the National Assembly with 15 deputies. According to one of the leading entrepreneurs of the country, Vehbi Koç, the two most important events of 1965 were the rapid increase in population and the TLP's entrance into the parliament. ${ }^{46}$

For the party members, the most important and meaningful result of the 1965 elections was not the JP's so-called victory but the TLP's electoral performance. For Boran, for instance, "with the entrance of fifteen socialist deputies to the Assembly, a critical point in the political life and development of the country has been overcome."47 In a circular from TLP's chairman Aybar, written just after the elections and representing the enthusiasm of the party in this period, it was stated that the 1965 elections “are our laboring people's first firm step on the road to power. This step will be followed by the second and third ones. And our laboring people... will certainly get power." 48

Most of the TLP's deputies were the members of its central bodies. This situation made the parliament and parliamentary activity very important and crucial for the party's life. The leadership of the party began to see parliamentary struggle as its essential means of propaganda for influencing people. ${ }^{49}$ They were very optimistic about the TLP's struggle in the parliament. "In the capitalist system", Aybar claimed, "parliament is the most effective platform for socialist parties. Parliament mirrors parties. What these parties are and whose side they are on clearly come into light." He asserted that the TLP had become the laboring people's voice in the parliament. Henceforth, there was a socialist opposition in the Assembly whose political weight was much greater than its numerical weight. ${ }^{50}$

The TLP was determined to establish a socialist government in the country by using parliamentary means. However, in the political history of Turkey, there was no such tradition that might have helped the TLP in its parliamentary activities. Deputies of the party had no parliamentary experience and were as such all amateurs. But, "of course, this amateurishness did not last long. In a short time, as single deputies and as a political party group, we learned our rights and duties and how the parliament functioned." ${ }^{51}$ On every issue that was discussed in the National Assembly or in parliamentary commissions, the TLP had a chance to state its views so that it could affect governmental work and propagate its ideas for influencing the public. The TLP also had opportunities to place any issue on the agenda by putting 
forward legislative proposals, and submitting oral or written questions, proposing motions for general discussion and censure. Parliamentary discussions for the budget provided another opportunity for the TLP to debate the work and problems of the government and to propagate party ideas. ${ }^{52}$ It was claimed that the main motive in these parliamentary activities of the TLP was to defend the constitution and the general and daily interests of the laboring people.

From their first speeches in the Assembly, the TLP's deputies set the party's own ideology against that of the JP. The TLP's leadership, by slightly exaggerating the TLP's influence in the parliament, claimed that it functioned as the main opposition party in the parliament; and the real struggle was between the JP and the TLP. For the TLP leadership there was no essential difference between the policies of the RPP and the JP. Despite the RPP leadership's decision to move the party to the left of the center of the Turkish political spectrum in the process of the polarization of the political life in the left and right wings in 1965, just before the general elections, the TLP's relation with the RPP was not so much friendly in this period. They were quite careful to distinguish the TLP's political stance from that of the RPP. The "so called" turn of the RPP to the left was, according to the TLP leadership, just a political tactic to slow down the political rise of the TLP. ${ }^{53}$

The TLP's main criticism of the performance of the JP was that the JP ignored the social character of the constitution and sought to impede its complete implementation. As a political organization representing the interests of the ruling classes, the JP interpreted the constitution in favor of landlords and the big bourgeoisie and had passed laws which were essentially against the constitution. The TLP, on every occasion, tried to prove that the government's general policy, its legislative proposals, bills and resolutions, were unconstitutional. ${ }^{54}$ For instance, in a long speech on November 7, 1965, Aybar, following the party's general ideological line, attacked the new government's program. He stated that contrary to the government's belief, there was a regime crisis in Turkey as the present regime and its government contradicted the constitution. He maintained that the TLP, by differing from the new government, stood for a planned economy and statism; in other words, a non-capitalist path of development and reform in land-holding, and was against the domination of private enterprise and the encouragement of foreign investments by Turkish governments. Aybar's critique of the new government's foreign policy, however, was the most shocking part of the speech: He raised the question of the US bases in Turkey and Turkey's bilateral agreements with the US and asserted that "today in Turkey, thirty-five million square meters of soil of our fatherland are under American domination." 55 After this speech, the National Assembly witnessed many other trenchant speeches by TLP deputies. ${ }^{56}$

In the course of time, the TLP's opposition to the JP led to a bitter dispute between these parties. The TLP's critiques of the government were answered by the JP's growing counter-attacks. In their speeches, members of the JP in the National Assembly accused the TLP of being a communist party and of stepping outside the boundaries of the constitution. Their claim was that the TLP used the constitution to mask its real aims and was not in fact a party that represented the interests of the 
laboring people. For example, Prime Minister Demirel, in a speech in February 1967, stated "people who have a fancy for, openly or secretly, propagating communism... are adopting an attitude contrary to the national interests... Interpreting the Turkish constitution as the protector of communism and Marxism is insolence." He added: "The Turkish constitution does not envisage socialism or communism. The Turkish constitution does not envisage class struggle. The Turkish constitution does not give the freedom to spread communism." 57

The campaign against the TLP was not only carried out by the JP in the parliament; it was also carried out by the other institutions of the state. For example, attacking the main political argument of the TLP in 1967, the president of the Turkish Republic, Cevdet Sunay, in his May 27 message on the anniversary of the 1960 military intervention, stated that the constitution was closed to socialism. ${ }^{58}$ After this message Aybar was replying with frustration that "while there is a socialist party in the National Assembly, the statements of Mr. President announcing that our constitution is closed to socialism is a regretful intervention meaning the negation of multi-party political life." $" 59$ This was not the last attempt of the president to portray the TLP as a political party not acting within the framework of the constitution. During his visit to London in November 1967, Sunay was declaring that the constitution was also closed to "democratic" and parliamentary socialism. In his message, he was expressing his suspicions about the legitimacy of the TLP in the Turkish political system. ${ }^{60}$

The attacks of the JP against the TLP's deputies were directed especially at Çetin Altan, one of the most popular leftist journalists of the 1960s. His speeches in the National Assembly and his writings irritated all the parties, but especially the JP. But, the strife between the TLP and the JP reached its highest point in February 1968 when the discussions on the budgets of the Ministry of the Interior took place in the National Assembly. Throughout his speech, Minister of the Interior Faruk Sükan tried to prove that the methods and direction of the TLP were the same as those of communist parties, under the instruction of Moscow. This provocative speech led to a quarrel between the deputies of the two parties and ended with the physical attack by the JP's party group on the members of the TLP. ${ }^{61}$ In a speech the next day condemning the attack by the JP, Aybar stated that the statements of the government declaring that it was in favor of the freedom of thought and a democratic system had lost their persuasiveness. If a democratic system, he added, did not comprise both right and left wings, namely, representatives of both capitalists and laborers, and if the interests of these classes could not be expressed under the guarantee of the constitution, this regime was not democratic but clearly fascist. ${ }^{62}$

In his evaluation of the TLP's parliamentary performance years later, Aybar stated that after entering the National Assembly the TLP completely changed the political atmosphere of the place with a small number of deputies ${ }^{63}$ and, with this performance, became an important pillar of Turkish political life between 1965 and $1969^{64}$. Boran, adopting the same line as Aybar, claimed that with its 15 seats the TLP had raised the quality of politics in the National Assembly. The party had used 
the advantages of the parliament very effectively in order to criticize bourgeois power and its political representatives and spread the TLP's socialist views. The TLP had transformed the Assembly into a forum in which the party stood for the rights and freedoms of the laboring people and all oppressed and exploited masses. ${ }^{65}$ For Sadun Aren, another prominent leader of the party, deputies of the TLP with their views and personalities were strangers to parliamentary politics but, in the course of the time, had begun to determine the discussions that took place in the National Assembly. These discussions, according to Aren, contributed to the development of democracy in Turkey. ${ }^{66}$ With the defeat of the TLP in the 1969 general elections, ${ }^{67}$ however, the party began to lose its political impact both in the parliament and on the Turkish left in general. This defeat undermined the strategy of the TLP's line on the attainment of power by peaceful means, thereby discrediting the TLP's ideology and putting an end to the political authority of the party over the other sections of the Turkish left. ${ }^{68}$

\section{Conclusion}

The TLP's entry into the National Assembly was one of the most significant and interesting developments of the period following the military intervention of 1960. As the main legal organization of the Turkish left in the 1960s, the party openly represented a kind of radicalism in the Assembly, bringing a new political understanding and vision to the parliament. It openly described itself as the political organization of the workers and laborers and tried to stand for the political and economic interests of this class. The TLP opposed the political strategies of the other parties represented in the parliament and supported new radical solutions for the economic and social problems of the country.

As Sayarı puts it, "the polarization of Turkish politics on a left-right continuum became much more discernible after 1965 with the TLP's representation in the Assembly." ${ }^{69}$ As a socialist party in the parliament, the TLP was always the target of attacks of right-wing parties. The representation of a radical leftist party in the parliament openly propagating its ideas and attacking the mainstays of the regime was unusual and unacceptable to these parties. The Turkish political structure and tradition were strangers to a party like the TLP, so it was almost impossible for the party to be accepted by this structure and to become institutionalized in it.

The party was determined to construct socialism in the country by using constitutional and parliamentary means. The leaders of the party believed that the TLP would develop into a mass party and come to power through parliamentary elections. From its foundation, the ideologists of the party claimed that the 1961 constitution provided a legal framework for the party within which to come to office by winning a majority in the parliament was possible. They continuously rejected nonparliamentary methods and the idea that socialism could be built by coups or guerilla strategies.

However, the emergence of factional controversies within the party towards the end of 1960s and, of course, its defeat in the 1969 general elections, almost terminated 
the TLP's political strength in the parliamentary arenas and its political impact on the Turkish left. The TLP was unable to create a powerful historical/political tradition in the Turkish political structure. The political legacy of the party concerning the strategy for seizing power did not have a serious influence on the later development of the Turkish left. This legacy was not perpetuated by the generations that followed. Turkish socialists have been unable either to repeat or to proceed beyond the parliamentary experience of the TLP for decades. The rejection of the TLP's program and ideology by the Turkish political system and a large section of the Turkish left determined the political fate of the party. The TLP never regained its former political strength. The party, in the course of the time, became marginalized and turned into one of the small sects of the Turkish left in the second half of the 1970s.

\section{Acknowledgements}

I would like to thank Prof. Erik-Jan Zürcher from the International Institute of Social History (IISG), Amsterdam, for hosting me as a visiting fellow at the Institute. This article was completed during my archival research at the IISG, which was sponsored by TUBITAK. I would also like to thank Dr. Tuba Kanc1 (Koc University, Istanbul) for her support during my research.

\section{Notes}

1. Although insistently supporting parliamentary methods to come to power, the political life of the TLP cannot be confined to its parliamentary efforts. The TLP was also employing non-parliamentary means, and it was active outside the parliament. However, in this article, I will confine my inquiry to the TLP's parliamentary activity.

2. For an influential account of the political history of Turkey in the 1960s see, Feroz Ahmad, The Turkish Experiment in Democracy: 1950-1975 (London: C. Hurst \& Company, 1977).

3. Behice Boran, Türkiye ve Sosyalizm Sorunlart [Turkey and the Problems of Socialism] (İstanbul: Gün Yayınları, 1968), pp. 59-60.

4. Mehmet Ali Aybar, Bă̆ımsızlık, Demokrasi, Sosyalizm [Independence, Democracy, Socialism] (İstanbul: Gerçek Yayınları, 1968), pp. 179-188.

5. See, Kemal H. Karpat, "Socialism and the Labor Party of Turkey", Middle East Journal, 23 (Spring 1967), p. 157; and Kemal H. Karpat, "Ideology in Turkey after the Revolution of 1960" in Social Change and Politics in Turkey, edited by Kemal H. Karpat (Leiden: E.J.Brill, 1973), p. 341. It should be noted that there is a very limited number of works written in English about socialism in the 1960s. Two important books in English dealing with the topic are as follows: Jacob M. Landau, Radical Politics in Modern Turkey (Leiden: E.J. Brill, 1974); and Igor P. Lipovsky, The Socialist Movement in Turkey, 1960-1980 (Leiden: E.J. Brill, 1992).

6. Çağlar Keyder, "The Political Economy of Turkish Democracy" in İ.C. Schick and E.A. Tonak (eds), Turkey in Transition, (Oxford: Oxford University Press, 1987), p. 52.

7. Ahmet Samim, "The Left", in İ.C. Schick and E.A. Tonak (eds), Turkey in Transition (Oxford: Oxford University Press, 1987), p. 154.

8. For the Yön movement see, Hikmet Özdemir, Kalkınmada Bir Strateji Arayışı: Yön Hareketi [A Quest for a Strategy for Development: The Yön Movement] (Ankara: Bilgi Yayınevi, 1986).

9. Yön, no. 1 (December 1, 1961), pp. 12-13. The statement was translated into English by Frank Tachau, Middle Eastern Affairs, Vol. 14, No. 3 (March 1963), pp. 75-78. The signatories who 
backed the statement held different ideological and political views and belonged to different political party and organizations. Among them were members of the left of the Republican People's Party (RPP) as well as socialists close to Marxism.

10. Ibid., p. 75.

11. For Belli's account of the concept of NDR see, Mihri Belli, Milli Demokratik Devrim [National Democratic Revolution] (Ankara: Şark, 1970).

12. Erich Jan Zürcher, Turkey: A Modern History (Leiden: E.J. Brill, 1993), p. 259.

13. See, Sadun Aren, TiP Olayl, 1961-1971 [The TLP Incident, 1961-1971] (İstanbul: Cem Yayınevi, Kasim 1993), p. 31.

14. TIP, II. Büyük Kongresi Alınan Kararlar ve Yapılan Seçimlerin Sonuçları [The Second Grand Congress of the TLP, Congress Decisions and Congress Election Results], 1966, p. 6.

15. Çetin Yetkin, Türkiye'de Soldaki Bölünmeler (1960-1970) [Rifts within the Turkish Left (19601970)] (Ankara: Toplum Yayınları, Mayıs 1970).

16. TiP, IV. Büyük Kongresi Alınan Kararlar ve Yapılan Seçimlerin Sonuçları [The Fourth Grand Congress of the TLP, Congress Decisions and Congress Election Results], 1970.

17. TIP, Türkiye İşçi Partisi Programı [The Program of the TLP] (İstanbul: 1964), p. 69.

18. Doğan Avcıŏglu, Türkiye'nin Düzeni [The System of Turkey] (Ankara: Bilgi Yayınevi, 1969), p. 509.

19. Doğan Avcıŏ̆lu, "İnanç Buhranı" [The Crisis of Faith], Yön, no. 11 (February 28, 1962), p. 3.

20. Avcioğlu, Türkiye'nin Düzeni, p. 523.

21. Ibid., p. 509.

22. Mihri Belli, Yazılar (1965-70) [Writings (1965-1970)]; (Ankara: Sol Yayınları, 1970), pp. 194.

23. For student activism see, Joseph Szyliowicz, A Political Analysis of Student Activism: The Turkish Case (London: Sage Publications, 1972).

24. An interesting point that should be noted is that, before the intervention, the majority of the leftist tendencies expected a leftist military coup. Especially the NDR militants and the Yön group foresaw a revolutionary junta as imminent. Even just after the intervention, a majority of the leftist groups published proclamations supporting the military's assumption of power. See, Samim (1987), pp. 158-160.

25. Behice Boran, İki Açıdan Türkiye İşçi Partisi Davası [Two Aspects of the Trial of the Turkish Labor Party] (İstanbul: Bilim Yayınları, 1975), p. 101.

26. Murat Sarıca, 1961 Anayasasinin Sosyal Niteliği [The Social Quality of the 1961 Constitution] (Istanbul: Karınca Matbaası, 1966), pp. 12, 20-21.

27. Ibid., p. 62.

28.Aybar, Bă̆ımslzlık, Demokrasi, Sosyalizm, p. 600

29. Boran, Türkiye ve Sosyalizm Sorunları, pp. 222-224.

30. TİP, Güzel, Mutlu Günler Uzak Değildir... Ve de Asıl Yüreğimiz Korkusuz, İnancımız Bütündür [Happy Days are not Far Away... And Our Heart is Fearless, Our Faith is Complete], 1965, p. 16

31. Joseph S. Szyliowicz, "The Turkish Elections: 1965," Middle East Journal, Vol. 20, No. 4 (1966), p. 473.

32. Tİ, Seçim Bildirisi [Election Manifesto] (İstanbul: Yenilik Basımevi, 1965), p. 3.

33. Ibid., pp. 24-25.

34. Ibid., pp. 8-9.

35. "Türkiye İşçi Partisi Bağışlarınızı Bekliyor" [The Turkish Labor Party is Waiting for Your Donations], Sosyal Adalet, no. 17 (August 1965), p. 11.

36. The main goal of the association was to fight against communism in Turkey. This extreme rightist organization was founded in 1963. The number of its branches throughout Turkey reached 110 in 1965. Landau, Radical Politics in Modern Turkey, pp. 203-204.

37. Nermin Abadan, 1965 Seçimlerinin Tahlili [The Analysis of the 1965 Elections] (Ankara: SBF Yayınlar1, 1968), p. 259.

38. See, for instance, Tỉ, 5-6 Mart Akhisar Olayları [March 5-6 Akhisar Events] (Başnur Matbaası, 1965), pp. 3-11. 
39. See, TïP, Türkiye İşçi Partisini Tanıyalım [Getting to Know the TLP] (Istanbul: Karınca Matbaası, 1965), pp. 11-14.

40. These candidates were grouped according to their profession as follows: workers, day laborers, farmers-101, trade unionists-27, craftsmen-27, tradesmen-23, drivers-6, house wives-4, journalists and writers-20, artists-3, teachers-18, retired teachers-10, officials-14, technicians-21, academics-4, retired officiers-15, engineers-11, lawyers-36, merchants and contractors-10, liberal professions- 22 . “Türkiye İşçi Partisi Adaylarının Tam Listesi”, Sosyal Adalet, no. 18 (September 1965), p. 42.

41. For the national remainder system see, C.H. Dodd, Politics and Government in Turkey (Manchester: Manchester University Press, 1969), p. 183.

42. The TLP's 15 deputies were Mehmet Ali Aybar (İstanbul)-lawyer, Rıza Kuas (Ankara)-trade unionist, Muzaffer Karan (Denizli)-retired officer, Tarı Ziya Ekinci (Diyarbakır)-doctor, Sadun Aren (İstanbul)-professor, Yahya Kanbolat (Hatay)-engineer, Cemal Hakkı Selek (İzmir)-lawyer, Adil Kurtel (Kars)-lawyer, Behice Boran (Urfa)-scholar, Yunus Koçak (Konya)-lawyer, Kemal Nebioğlu (Tekirdağ)- trade unionist, Ali Karcı (Adana)-printer, Yusuf Ziya Bahadanlı (Yozgat)teacher, Şaban Erik (Malatya)-trade unionist, and Çetin Altan (İstanbul)-journalist. Aclan Sayllgan, Türkiye'de Sol Hareketler(1871-1972) (İstanbul: Hareket Yayınlar1, 1972), p. 371.

43. Szyliowicz, "The Turkish Elections: 1965," p. 492.

44. Nermin Abadan and Ahmet N. Yücekök, "1961-1965 Seçimlerinde Büyük Şehirlerde Gelir Durumuna Göre Oy Verme Davranışları" [Voting Behaviors in the Metropoles with Respect to Income in the 1961 and 1965 Elections], Siyasal Bilgiler Fakültesi Dergisi, Vol. 24, No.4 (1966), pp. 108-109, 114.

45. The electoral performances of the other parties were as follows: the Nation Party won 31 seats, the New Turkey Party 19, and the Republican Peasant's Nation Party 11.

46. Mehmet Ali Aybar, TIP Tarihi [The History of the TLP], vol. 2 (Istanbul: BDS, 1988), p. 9.

47. "İşçi Partisi Adaylarına Sorular" [Questions for the Labor Party Candidates], Sosyal Adalet, no. 20 (1965), p. 26.

48. Aybar, Bă̆ımsızlık, Demokrasi, Sosyalizm, p. 432.

49. TİP, İkinci Kongre Çalışma Raporu [The Second Congress Working report], 1966, p. 38.

50. Doğan Özgüden, “Aybar'ın Ant'a Özel Demeci” [Aybar's Special Statement to Ant], Ant, (February 14, 1967), p. 9.

51. Aren, TiP Olay1, p. 168.

52. For some numbers and the detailed lists of the TLP's legislative proposals, oral and written questions, etc., that help illustrate the TLP's parliamentary performance between 1965 and 1969 see, T İP, Çalışma Raporu (1966), p. 39-42; TİP, Üçüncü Büyük Kongre Çalışma Raporu [The Third Grand Congress Working Report] (İstanbul: Latin Matbaas1, 1968), pp. 59-70.

53. For an account of the relation between the TLP and the RPP see, Lipovsky (1992). For the RPPs turn to the left in the second half of the 1960s see, Sinan Ciddi, Kemalism in Turkish Politics (London: Routledge, 2009).

54. TìP, Üçüncü Büyük Kongre Çalışma Raporu, pp. 64-66.

55. For this speech see, M.A. Aybar, Türkiye'yi Adalet Partisi Kalkındıramaz [The Justice Party cannot develop Turkey] (İstanbul: İstanbul Matbaası, 1966), p. 47.

56. The most influential spokesmen of the TLP in the parliament were Aybar, Boran, Aren and Çetin Altan. Some of their forceful speeches were published as pamphlets in a series titled The TLP in the Parliament. The first pamphlet of the series was Türkiye'yi Adalet Partisi Kalkındıramaz.

57. TBMM Tutanak Dergisi, 22 (February 9, 1967), p. 465.

58. "Sunay, Anayasa Sosyalizme Kapalıdır, Dedi" [Sunay Says, the Constitution is not Open to Socialism], Milliyet, May 28, 1967.

59. "Sunay'a Cevap" [Reply to Sunay], Ant, May 30, 1967, p. 3.

60. See, Aybar, TiP Tarihi, pp. 107-108. See also, Abdi İpekçi, "Sunay ve Sosyalizm" [Sunay and Socialism], Milliyet, November 14, 1967.

61. TBMM Tutanak Dergisi, 25, (February 19, 1968), pp. 372-381. This event, to a certain extent, showed the JP's intolerance of any opposition, especially that of the TLP. In this event two deputies 
of the TLP, Aren and Koçak, were injured. See, Çetin Altan, Ben Milletvekili İken [When I was a Member of Parliament] (Ankara: Bilgi Yayinevi, 1971), pp. 421-448.

62. TBMM Tutanak Dergisi, 25 (February 20, 1968), p. 402.

63. Aybar, TIP Tarihi, p.162.

64. Abdi İpekçi, Liderler Diyor Ki [The Leaders Say That] (Istanbul: Ant Yayınları, 1970), p.133.

65. Behice Boran, "TIP Tarihi”" [The History of the TLP], Çark Başak, no. 11 (1976), pp. 4-5.

66. Ahmet Hamdi Dinler, T IP Tarihinden Kesitler 1961-1971 [Fragments from the History of the TLP] (İstanbul: Gelenek Yayınevi, 1990), p.70. But there were also pessimistic accounts of the TLP's parliamentary experiences. For instance, Çetin Altan later wrote, in the course of time the parliamentary members of the TLP lost much of their early enthusiasm to be involved in parliamentary discussions. They also lost their optimistic belief that their speeches in the National Assembly would solve the problems of the country and enlighten the masses. They began to think that the speeches did not work at all. Altan, Ben Milletvekili İken, p. 78.

67. In the 1969 general elections, the TLP only received 243,631 votes, or 2.58 percent of the total votes, and won only two seats in the parliament. The representatives of the party were Aybar and Kuas.

68. Why did the TLP fail to mobilize the Turkish electorates in large numbers? Several explanations can be offered. One of the typical features of the socialist movement in Turkey in the 1960s was the deepening rift among different parts of the movement. The fierce polemics on political strategies and programmatic issues deepened the splits between the main factions of the movement. As I have already mentioned, the TLP was not immune from this process of fragmentation. The increasing factionalism within the party ranks and its leadership in the second half of the 1960s seemed to be one of the most important reasons of the TLP's failure to establish itself as an effective political force in Turkey. Within this process of fragmentation, the TLP failed to channelize the radicalization of social groups and strata like university students, workers and peasants, in the late 1960s, into a permanent political support to the party. Moreover, on the parliamentary platform, the TLP lost its monopoly of being the only political option for the leftist electorates after 1965. The RPP with its adaptation of the center-left strategy appeared as an alternative to the TLP in the competition to win the hearts and minds of the leftist constituents. Besides, there had been no serious legal and parliamentary experience and tradition in the history of socialist movement in Turkey from which the TLP could borrow; and this also hindered the party from being a serious political factor in the Turkish political life. The party's lack of experience and tradition was accompanied with the denial of the party and its program by the mainstream political actors, parties, institutions and traditions; the denial, which, in the political climate of the Cold War, was turned into a strong anti-leftist sentiment in the common public opinion.

69. Sabri Mustafa Sayarı, Party Politics in Turkey: Dimensions of Competition and Organization (Columbia University, PhD Thesis, 1972), p. 241. 